\title{
$\mathrm{AHP}$ 를 이용한 농촌관광단지 입지선정에 관한 연구 -부여군을 중심으로-
}

\section{A Study on Agricultural Village Tourism Complex Positioning using Analytic Hierarchy Process: The Case of Buyeo-gun}

\author{
윤준상* • 최성현** - 김이기 ${ }^{* * *}$ - 김성록**** \\ Jun Sang Yoon • Sung Hyeun Choi • Yee Gi Kim • Sung Rok Kim
}

\section{Abstract}

There are many positioning studies utilizing Analytic Hierarchy Process (AHP) in tourism industry. In this study, it was tried to develop new evaluation criteria for positioning and to discuss the importance of evaluation factors, as the development of tourist's spots was pursued in diversified ways. The purpose of this study was to allow the development of tourist spots more objectively and more efficiently utilizing Analytic Hierarchy Process ("AHP" hereunder) to appoint the best place for the tourism complex in Buyeo. According to AHP analysis procedures, 5 places near Baikje Cultural Block connecting with a ferry in Buyeo-gun were selected as candidates. To perform AHP analysis, evaluation criteria and a survey were used and then weight of evaluation criteria was induced. With the conditions on criteria, standard score of each criterion and candidate was calculated. By multiplying standard score and final weight and

* 공주대학교 지역사회개발학과 교수. e-mail: jsyoon@kongju.ac.kr

** 공주대학교 지역사회개발학과 석사. e-mail: devilddoch@kongju.ac.kr

*** 농촌진흥청 국립식량과학원 농촌지도사. e-mail: kimyiki@korea.kr

**** 공주대학교 지역사회개발학과 박사과정. e-mail: isoiso@kongju.ac.kr 
then summing up, the candidate place with the highest score shall be appointed as the most optimal place for Buyeo-gun Agricultural Tourism Complex

주요어(key words): 계층적분석방법(AHP), 농촌관광단지(Agricultural Village Tourism Complex)

\section{1. 서 론}

관광지의 개발은 관광객 유치를 위한 자원의 정비와 관광매력물 창조, 국 민들의 휴식공간 확보 등의 측면에서 매우 중요하다. 따라서 미래지향적인 관광개발이나 계획은 관광입지 선정에서부터 과학적인 접근이 필요하다.

70 년대부터 관광지는 국민들의 건전한 관광여가장소로서 정부가 주도 적으로 개발하고자 하였으나 대부분의 관광지들이 지정만 되고 개발이 되지 못하였으며, 관광지가 개발된다 하여도 편의시설 부족 및 운영상의 미흡 등으로 관광객에게 만족을 주지 못하고 있는 실정이다. 이러한 이 유중에 하나는 관광지를 개발할 때 입지여건을 객관적이고 체계적으로 분석하지 못한 면을 지니고 있다.

따라서 관광지 개발은 먼저 관광지 입지 선정에 있어서 보다 체계적이 고 과학적인 방법에 의해 선택되어야 함을 의미하고 이러한 문제는 다기 준의사결정(multicriteria decision making: $\mathrm{MCDM}$ ) 분야에 적합한 주제라고 할 수 있다. 그 이유는 평가자나 의사결정자가 가진 다양한 기 준에 대한 주관적인 견해가 문제의 해결에 핵심적인 역할을 하고 있기 때문이다(Rangone, 1996). 이에 따라 평가자의 견해나 주관적인 선호 를 객관적으로 모형화하기 위해 많은 연구가 이루어져 왔으며, 분석적 계층과정(analytic hierarchy process: AHP)을 이용한 접근이 여러 
문헌들에서 시도된 바 있다(Al-Harbi, 2001; Ossadnik \& Lange, 1999; Bard, 1992; Falkner \& Benhajla, 1990).

관광분야에서의 입지선정에 관한 연구는 관광지입지선정, 관광농업입 지결정, 호텔입지선정, 패밀리레스토랑 입지선정 등 다양한 부문에서 연 구되고 있는데, 관광지 입지선정(고병주, 2009) 등에 계층분석법(AHP) 을 활용한 연구 등을 들 수 있다. 따라서 본 연구는 관광지 개발이 다각 적으로 추진됨에 따라 농촌 관광단지 입지선정에 있어 새로운 평가지표 를 개발하고 평가인자들의 중요도에 대한 논의가 필요한 시점이다.

일반적으로 관광지 개발에 있어 먼저 입지를 선정한 이후, 타당성 분 석 과정을 통해 적지를 선정하고 이를 합리화하는 경우가 대부분이다. 그렇기 때문에 오늘날 관광지의 적지선정은 객관성이 확보되는 정량적 체계적 의사결정이 아닌, 지역 간 이해관계 등과 같은 정성적·주관적인 요인이 상당부분 작용하여 합리적인 입지선정이 되지 못하고 있다.

따라서 본 연구는 농촌 관광단지 입지를 선정하는 과정에서 선행 연구 를 분석하여 고려해야 할 입지선정 평가인자와 이들 인자의 가중치를 파 악하여 최적 후보지를 도출하는 과정을 설명하고, 이에 대한 실증분석으 로 부여군 농촌관광단지 입지선정에 적용하도록 하겠다.

\section{2. 이론적 배경 및 선행연구고찰}

\section{1. 관광단지의 개념}

관광단지는 관광객의 다양한 관광 및 휴양을 위하여 각종 관광시설을 종합적으로 개발하는 관광거점지역(관광진흥법 제 2 조)을 말한다. 관광단 지는 관광객을 위하여 단지 내 기능(공공편익시설, 관광호텔 및 휴양콘 
도미니엄 등의 숙박시설, 휴양-놀이 운동시설, 관광공연장 등의 접객시 설)이 상호 의존적이고 단기체제에 적합하도록 인위적으로 개발되는 곳 이다(김성진, 2005).

법률에서 정하고 있는 “관광단지”는 관광객의 다양한 관광 및 휴양을 위하여 각종 관광시설을 종합적으로 개발하는 관광거점지역으로서 관광 진흥법에 의하여 지정된 곳으로 관광객을 위하여 단지 내 기능이 상호

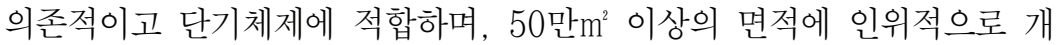
발된 곳을 의미한다(관광진흥법 제2조). 2010년 9월 현재 관광단지로 지정되어 개발을 추진 중이거나 운영 중인 관광단지는 29 개소가 있다.

\section{〈표 1〉관광단지 시설기준}

\begin{tabular}{|c|c|c|}
\hline 시설구분 & 시설종류 & 구비기준 \\
\hline 공공편익 & $\begin{array}{l}\text { 화장실, 주차장, 전기시설, 통신시 } \\
\text { 설, 상. 하수도시설, 관광안내소 }\end{array}$ & 각 시설이 관광객의 이용에 충분할 것 \\
\hline 숙박시설 & $\begin{array}{l}\text { 관광호텔, 수상관광호텔, 한국전통 } \\
\text { 호텔, 가족호텔, 휴양콘도미니엄 }\end{array}$ & $\begin{array}{l}\text { 관광객이용시설업의 등에 부합되는 것으 } \\
\text { 로서 3종류 이상일 것 }\end{array}$ \\
\hline $\begin{array}{l}\text { 운동 · } \\
\text { 오락시설 }\end{array}$ & $\begin{array}{l}\text { 골프장, 조정장, 카누장, 빙상장, } \\
\text { 자동차, 경주장, 승마장, 종합체육 } \\
\text { 시설, 경마장, 경륜장 및 경정장 }\end{array}$ & $\begin{array}{l}\text { 체육시설의 설치 · 이용에 관한 법률 제 } \\
10 \text { 조의 규정에 의한 등록체육 시설업의 } \\
\text { 등록기준, 한국마사회법시행령 제 } 5 \text { 조의 } \\
\text { 규정에 의한 시설 설비기준 또는 경륜. } \\
\text { 경정법시행령 제 } 5 \text { 조의 규정에 의한 시설 } \\
\text { /설비 기준에 부합되는 것 }\end{array}$ \\
\hline $\begin{array}{l}\text { 휴양 } \\
\text { 문화시설 }\end{array}$ & $\begin{array}{l}\text { 민속촌, 해수욕장, 수렵장, 동물 } \\
\text { 원,식물원, 수족관, 온천장, 동굴자 } \\
\text { 원, 수영장, 농어촌유양시설, 산 } \\
\text { 림휴양시설, 박물관, 미술관, 활 } \\
\text { 공장, 자동차야영장, 관광유람선, } \\
\text { 종합유원시설업 }\end{array}$ & $\begin{array}{l}\text { 관광객이용시설업의 등록기준 또는 유원 } \\
\text { 시설업의 설비기준에 부합 }\end{array}$ \\
\hline 접객시설 & $\begin{array}{l}\text { 관광공연장업, 외국인용관광기념 } \\
\text { 품판매점, 관광유흥음식점, 외국 } \\
\text { 인전용유흥 음식점, 관광식당업 } \\
\end{array}$ & $\begin{array}{l}\text { 관광객이용시설업의 등록기준 또는 관광 } \\
\text { 편의시설업의 지정기준에 적합한 시설로 } \\
\text { 서 관광객의 이용에 충분할 것 }\end{array}$ \\
\hline 지원시설 & $\begin{array}{l}\text { 관광종사자 전용숙소, 관광종사자 } \\
\text { 연수시설, 물류·유통관련 시설 }\end{array}$ & $\begin{array}{l}\text { 관광단지의 관리·운영 및 기능활성화를 } \\
\text { 위해서 필요한 시설 }\end{array}$ \\
\hline
\end{tabular}




\section{2. 계층적분석방법 $(\mathrm{AHP})$ 개요}

계층적분석방법 $(\mathrm{AHP})$ 은 의사결정요소들의 속성과 그 측정 척도가 다 양한 다기준의사결정문제에 효과적으로 적용되어 의사결정자가 선택할 수 있는 여러 가지 대안들을 체계적으로 순위화시키고, 그 가중치를 비 율척도(ratio scale)로 도출하는 방법을 제시한다(Saaty, 1980). 다수 가 참여하는 의사결정문제에 있어서 사용될 수 있는 중요한 의사결정지 원방법론으로, 정량적인 분석이 곤란한 의사결정 분야에 전문가들이 정 성적인 지식을 이용하여 경쟁되는 요소의 가중치 또는 중요도를 구하는 데 유용하게 응용될 수 있다(남인석 \& 김충영 1994 ; 김영규 \& 노시천 1997). 다수의 목표, 다수의 평가 기준, 다수의 의사결정 주체가 포함되 어 있는 의사결정 계층화하여 해결하는 데 있다. 여러 명의 의사결정자 가 참여하여 의사결정과정에서 계층화되어 있는 다양한 기준들을 계층화 하여 기준들 간의 상대적 중요도(relative importance)나 가중치(weight) 를 쌍대비교를 통해 구함으로 최종적으로 여러 사업대안들의 우선순위를 구하는 방법이다. $\mathrm{AHP}$ 는 단위가 포함되지 않는 숫자를 활용함으로써 각종 요소를 동시에 고려할 수 있는 장점이 있는 반면 지표별 영향력이 일원화된다는 한계를 가지고 있다. 평가기준들 간에 상대적 중요도를 고 려함으로써 사업대안들에 대한 우선순위를 구할 수 있다는 점과, 일관성 검증으로 비논리적 설문답안을 제거하여 평가기준들에 대한 가중치를 계 산함으로 다양한 요소를 일목요연하게 정리, 활용할 수 있는 장점이 있 는 반면 모델 설정을 위한 지표선정 과정에서 조사자의 주관적인 판단이 개입될 수 있는 문제점을 동시에 가지고 있다. 


\section{3. 선행연구 고찰}

고병주(2009)는 의사결정 요소를 크게 접근성, 개발용이성, 자연자 원, 인문자원 으로 나누고 그 세부 항목으로는 교통수단, 접근거리, 토지 이용, 토지매입의 용이성, 투자유치 가능성, 정부지원제도로 제시하였으 며, 박재현(2004)은 접근성, 자연 입지성, 토지 이용성, 기반시설, 경제 성으로 크게 항목을 잡고 그 세부 항목으로는 접근용이성, 접근편의성, 주요관광지와의 인접성, 기상조건, 지형조건, 토지이용 제약성, 토지이용 가능성, 진입로 개설여부, 용수공급의 용이성, 사업추진성, 투자계획의 합리성, 재원조달 능력으로 나누었다.

김대관, 박양우, \& 이상민(2007)은 크게 시설의 매력성, 시설의 환경 성, 시설의 시장성, 시설의 실현가능성으로 크게 분류하고, 그 세부항목 으로는 시설 고유성, 시설 차별성, 시설 계절성, 시설 적합성, 시설 환경 성, 시설 연계성, 시설 배후성, 사업 타당성, 미래 지향성, 정책 부합성, 제약성, 수요 적정성, 투자 합리성으로 세부항목으로 나누었고, 오정한 (2010)은 경관조성, 편의시설, 접근성, 관광상품, 홍보활동, 경영투명, 주민참여, 교육, 운영관리로 크게 항목을 나누고, 세부 항목으로는 통일 성있는 연출, 환경과의 조화, 보존을 통한 개발, 편의시설 확충, 안내표 지판 설치, 시설의 효율적 배치, 이정표 설치, 도로 확충, 교통수단 증 대, 관광상품 개발, 주변지역과의 연계, 축제활성화, 안내시스템 구축, 홍보수단의 다양화, 사업의 면밀도 검토, 집행의 투명성, 공감대 형성, 갈등해소 방안 마련, 주민의견 수렴, 서비스교육, 관광안내원 육성, 운영 매뉴얼 개발, 관광객 프로그램으로 나누었다. 우찬복 \& 문경일(1999)은 관광지 입지선정 요인으로 자연환경, 인문환경, 관광환경으로 큰 항목을 정하고, 자연환경의 세부항목으로 지형, 기후, 식생, 지질-토양, 수문을 평가항목으로 선정하였고, 인문환경의 세부항목으로 토지이용현황·지 
가, 교통, 기존시설 및 지장물, 관련법규, 역사적 유산을, 관광환경의 세 부항목으로 위치 및 세력권, 주변지역의 관광자원, 경관 및 주변부존자 원, 주변관광권 개발계획, 관광산업의 발달로 평가항목을 선정하였다.

\section{3. 분석방법 및 데이터}

\section{1. 분석 도구}

본 연구의 평가항목을 설정하기 위하여 위와 같은 선행연구를 검토하 여 3개의 (1) 교통 접근성, (2) 개발 용이성, (3) 관광 환경으로 설정하고, 9 개의 세부 항목지표를 도출하였다. 이 설정항목을 토대로 관련학과 교 수 및 박사급연구원 5 명을 대상으로 예비조사를 실시하여 최종평가항목 을 도출하였다. 최종평가항목은 크게 교통접근성, 개발용이성, 관광환경 으로 나누고, 세부항목으로 국도와의 접근, 터미널과의 접근, 개발 비용, 부지확보 용이성, 인허가 절차의 용이성, 민원발생 가능성, 주변관광시 설 연계성, 주변 환경으로 8 개의 지표를 도출하였다.

〈표 2〉최종 평가항목 및 기준 설정

\begin{tabular}{c|l|l}
\hline \multicolumn{2}{|c|}{ 평 가 지 표 } & \multicolumn{1}{c}{ 설 명 } \\
\hline \multirow{2}{*}{ 교통 } & 국도와의 접근 & -국도에서 입지 후보지까지 거리(인접한 국도) \\
\cline { 2 - 3 } 접성 & 터미널과의 접근 & -부여시외버스터미널에서 입지 후보지까지의 거리 \\
\hline \multirow{4}{*}{$\begin{array}{c}\text { 개발 } \\
\text { 용이성 }\end{array}$} & 개발 비용 & -토목 공사비, 진입로 공사비 \\
\cline { 2 - 3 } & 부지확보 용이성 & -후보지역 토지매입비 \\
\cline { 2 - 3 } & 인허가 절차의 용이성 & -용도지역 및 제한구역 \\
\cline { 2 - 3 } & 민원발생 가능성 & $\begin{array}{l}\text {-민원발생 가능성(인접주민, 상권 등 민원발생소지 } \\
\text { 가 적은 부지가 유리) }\end{array}$ \\
\hline
\end{tabular}




\begin{tabular}{c|l|l}
\hline \multirow{2}{*}{$\begin{array}{l}\text { 관광 } \\
\text { 환경 }\end{array}$} & 주변관광시설 연계성 & $\begin{array}{l}\text {-주변 관광지를 찾는 관광객들 동선 거리 } \\
\text { (백제문화단지, 나루터, 궁남지 등에서의 지역 접근) }\end{array}$ \\
\cline { 2 - 4 } & 주변 환경 & -후보입지와 주변지역의 친수성, 입목도 등 \\
\hline
\end{tabular}

\section{2. 분석데이터}

부여군 농촌관광단지의 후보지로는 백마강 나루터와 백제문화단지를 활용할 수 있는 부여군 내 5 개 지역을 후보지를 대상으로, $\mathrm{AHP}$ 설문을 통하여 최적 지역을 선정하고자 한다. 설문대상은 부여군 내에 체험시설 운영자, 관광 관련 협회장, 관련 정부기관 종사자, 해당 지역 이장단 등 농촌개발 및 관광개발 관련 지역전문가 총 35 명을 대상으로 설문을 실시 하였으며, 설문에 적합하지 아니한 5 부를 제외한 총 30 부가 반영되었다.

\section{〈표 3〉 후보지별 특징}

\begin{tabular}{|c|c|}
\hline 후보지 & 특징 \\
\hline $\begin{array}{c}\mathrm{A} \text {-규암면 } \\
\text { 호암리 일대 }\end{array}$ & $\begin{array}{l}\mathrm{A} \text { 후보지는 백마강교를 지나 다리 아래쪽에 위치하고 있으며, 백제문화 } \\
\text { 단지와 } 1.2 \mathrm{~km} \text { 정도 떨어져 위치하고 있으며, 후보지 앞에 백마강이 흐 } \\
\text { 르고 주변 입목도가 좋으며, 백마강교를 통해 백제문화단지로 이동하는 } \\
\text { 관광객들에게 쉽게 눈에 띨 수 있을 것으로 보인다. }\end{array}$ \\
\hline $\begin{array}{l}\text { B-규암면 } \\
\text { 신리 일대 }\end{array}$ & $\begin{array}{l}\mathrm{B} \text { 후보지는 청양 및 보령에서 국도를 이용해서 부여로 오는 관광객들에게 } \\
\text { 접근성이 좋으나, 마을을 통하여 접근해야 하는 어려움이 있고, 백제나루 } \\
\text { 터 맞은편에서 보이는 지역으로 앞에 백마강이 흐르며 현재 } 4 \text { 대강 사업에 } \\
\text { 서 부지가 확보된 상태 이므로 이곳으로 관광단지가 들어서게 되어 사업 } \\
\text { 을 착수 할 경우에는 도 또는 군의 협의가 필요하다. }\end{array}$ \\
\hline $\begin{array}{l}\text { C-규암면 } \\
\text { 진변리 일대 }\end{array}$ & $\begin{array}{l}\mathrm{C} \text { 후보지는 고속도로로 접근하는 관광객 및 국도를 타고 오는 관광객 모 } \\
\text { 두 접근성이 뛰어나고 기관 및 관공서와의 접근성이 용이한 지역이고, } \\
\mathrm{B} \text { 후보지와 마찬가지로 백제나루터 맞은편에 보이는 지역으로 앞에 백 } \\
\text { 마강이 흐르고, 현재 } 4 \text { 대강 사업에서 부지를 확보한 상태이므로 도 또 } \\
\text { 는 군과의 협의가 필요하다. }\end{array}$ \\
\hline $\begin{array}{l}\mathrm{D} \text {-장암면 } \\
\text { 정암리 일대 }\end{array}$ & $\begin{array}{l}\mathrm{D} \text { 후보지는 백마강이 흐르고 있고, 하천 부지는 } 4 \text { 대강 사업지역으로 일대 } \\
\text { 하천 지역으로는 사업이 진행 중에 있고, 부지가 사유지로 되어 있어 이 } \\
\text { 곳에 사업이 진행된다면, 부지확보면에서 주민들과의 마찰이 우려된다. }\end{array}$ \\
\hline
\end{tabular}




\section{4. 분석결과}

\section{1. 가중치 도출}

계층화 구조를 바탕으로 $\mathrm{AHP}$ 설문조사를 통해 각 대안의 선호도에 각 평가항목별 가중치를 곱하여 대안별 최종 값을 계산한 후 쌍대비교를 통해 가중치를 도출한다. 의사결정의 가중치를 이끌어내기 위해 분석에 사용된 모든 평가자 각각의 가중치를 추정하고 일관성계수를 도출한 후 에 각 평가자들의 가중치 산술 평균값을 구하는 가중산술평균법을 이용 하여 최종 가중치를 추정하여 도출하였다.

〈표 4〉평가지표의 가중치

\begin{tabular}{c|c|c|c}
\hline \multicolumn{2}{|c|}{ 평 가 지 표 } & 가중치 & \multicolumn{1}{|c}{ 비 고 } \\
\hline \multirow{2}{*}{$\begin{array}{c}\text { 교통 접근성 } \\
(0.302)\end{array}$} & 국도와의 접근 (0.877) & 0.265 & $\begin{array}{l}\text { 청양, 보령, 공주, 논산으로 접근하는 국 } \\
\text { 도(4번국도, 29번국도, 40번국도 등) }\end{array}$ \\
\cline { 2 - 5 } & 터미널과의 접근 (0.123) & 0.037 & $\begin{array}{l}\mathrm{A}: 6 \mathrm{~km}, \mathrm{~B}: 5.5 \mathrm{~km}, \mathrm{C}: 3.5 \mathrm{~km} \\
\mathrm{D}: 11 \mathrm{~km}, \mathrm{E}: 13 \mathrm{~km}\end{array}$ \\
\hline \multirow{2}{*}{$\begin{array}{c}\text { 개발 용이성 } \\
(0.257)\end{array}$} & 개발 비용 (0.288) & 0.074 & $\begin{array}{l}\text { 각 지역 간 쌍대비교하여 개발비용이 } \\
\text { 적게 드는 지역 }\end{array}$ \\
\cline { 2 - 5 } & 부지확보 용이성 (0.364) & 0.094 & $\begin{array}{l}\text {-토지매입비(공시지가기준) } \\
\mathrm{A}, \mathrm{B}, \mathrm{C} \text { 지역은 국· 공유지/ } \\
\mathrm{D}, \mathrm{E} \text { 지역은 사유지 }\end{array}$ \\
\hline
\end{tabular}




\begin{tabular}{|c|c|c|c|}
\hline \multirow{2}{*}{$\begin{array}{l}\text { 개발 용이성 } \\
\quad(0.257)\end{array}$} & 인허가 절차의 용이성 (0.185) & 0.048 & 용도지역 및 제한구역 \\
\hline & 민원발생 가능성 (0.163) & 0.042 & $\begin{array}{l}\text { 인접주민, 상권 등 민원발생소지가 적 } \\
\text { 은 부지 }\end{array}$ \\
\hline \multirow{2}{*}{$\begin{array}{l}\text { 관광 환경 } \\
(0.441)\end{array}$} & 주변관광시설 연계성 (0.654) & 0.288 & $\begin{array}{l}\text { 백제문화단지, 나루터, 궁남지 등에서의 } \\
\text { 지역접근이 용이한 지역 }\end{array}$ \\
\hline & 주변환경 (0.346) & 0.152 & $\begin{array}{l}\text { 주변지역과의 친수성, 입목도 등이 좋 } \\
\text { 은 지역 }\end{array}$ \\
\hline
\end{tabular}

\section{2. 평가지표의 표준점수}

\subsection{1. 표준점수 기준}

세부항목 국도와의 거리는 $\mathrm{A}$ 후보지 $1.56, \mathrm{~B}$ 후보지 $1.25, \mathrm{C}$ 후보지 1.26 , D후보지 $0.81, \mathrm{E}$ 후보지 0.49 의 값으로 나타났으며, 이에 따른 표준점수는 $\mathrm{A}$ 후보지 $1.15, \mathrm{~B}$ 후보지 $0.41, \mathrm{C}$ 후보지 $0.45, \mathrm{D}$ 후보지 -0.62, E후보지 -1.39 로 도출되었다. 터미널과의 거리에서 $\mathrm{A}$ 후보지는 $6.0 \mathrm{~km}, \mathrm{~B}$ 후보지 $5.5 \mathrm{~km}, \mathrm{C}$ 후보지 $3.5 \mathrm{~km}$, D후보지 $11.0 \mathrm{~km}, \mathrm{E}$ 후보지 $13 . \mathrm{km}$ 로 나타났으며, 이에 따른 표준점수는 $\mathrm{A}$ 후보지 $-0.45, \mathrm{~B}$ 후보지 -0.57, C후보지 - 1.07 , D후보지 0.78, E후보지 1.30으로 나타났다. 개발비용으로는 토목 공사비, 진입로 공사비 등으로 고려해 보았을 경 우, 표준점수는 $\mathrm{A}$ 후보지 $1.41, \mathrm{~B}$ 후보지 $0.48, \mathrm{C}$ 후보지 $-0.09, \mathrm{D}$ 후보 지 $-0.62, \mathrm{E}$ 후보지 -1.17 로 분석되었으며, 부지확보 용이성에 따른 표 준점수는 $\mathrm{A}$ 후보지 $-0.72, \mathrm{~B}$ 후보지 $-0.72, \mathrm{C}$ 후보지 $-0.72, \mathrm{D}$ 후보지 $0.86, \mathrm{E}$ 후보지 1.31 로 나타났다. 인허가 절차의 용이성으로는 용도지역 및 제한구역이 적은 지역으로 각 후보지별로 쌍대비교하여 나오는 값으 로 고려해 보았을 경우에 표준점수는 $\mathrm{A}$ 후보지 $1.19, \mathrm{~B}$ 후보지 $0.62, \mathrm{C}$ 후보지 $0.23, \mathrm{D}$ 후보지 $-0.84, \mathrm{E}$ 후보지 -1.20 으로 나타났다. 민원발생 가능성, 주변관광시설의 연계성, 주변환경 등과 같은 세부항목별 세부지 
표 값과 표준점수는 〈표 5〉와 같다.

〈표 5〉세부지표 값 및 표준점수

\begin{tabular}{|c|c|c|c|c|}
\hline 세 부 지 표 & 후보지 & 값 & 표준점수 & 비고 \\
\hline \multirow{5}{*}{ 국도와의 거리 } & $\mathrm{A}$ & 1.56 & 1.15 & \multirow{5}{*}{$\begin{array}{l}\text {-청양, 보령, 공주, 논산으로 접근하는 } \\
\text { 국도(4번국도, } 29 \text { 번국도, } 40 \text { 번국도 등) }\end{array}$} \\
\hline & $\mathrm{B}$ & 1.25 & 0.41 & \\
\hline & $\mathrm{C}$ & 1.26 & 0.45 & \\
\hline & $\mathrm{D}$ & 0.81 & -0.62 & \\
\hline & $\mathrm{E}$ & 0.49 & -1.39 & \\
\hline \multirow{5}{*}{ 터미널과의 거리 } & $\mathrm{A}$ & 6.00 & -0.45 & \multirow{5}{*}{$\begin{array}{l}\text {-부여시외버스터미널에서 입지 후보지 } \\
\text { 까지의 거리 }\end{array}$} \\
\hline & B & 5.50 & -0.57 & \\
\hline & $\mathrm{C}$ & 3.50 & -1.07 & \\
\hline & $\mathrm{D}$ & 11.00 & 0.78 & \\
\hline & $\mathrm{E}$ & 13.00 & 1.30 & \\
\hline \multirow{5}{*}{ 개발비용 } & $\mathrm{A}$ & 1.67 & 1.41 & \multirow{5}{*}{$\begin{array}{l}\text {-토목 공사비, 진입로 공사비 } \\
\text { (각 지역 간 쌍대비교하여 개발비용 } \\
\text { 이 적게 드는 지역) }\end{array}$} \\
\hline & B & 1.27 & 0.48 & \\
\hline & $\mathrm{C}$ & 1.03 & -0.09 & \\
\hline & $\mathrm{D}$ & 0.80 & -0.62 & \\
\hline & $\mathrm{E}$ & 0.56 & -1.17 & \\
\hline \multirow{5}{*}{ 부지확보 용이성 } & A & 0.00 & -0.72 & \multirow{5}{*}{$\begin{array}{l}\text {-토지매입비(공시지가)가 적게 드는 지역 } \\
-\mathrm{A}, \mathrm{B}, \mathrm{C} \text { 지역은 국·공유지 } \\
-\mathrm{D}, \mathrm{E} \text { 지역은 사유지 }\end{array}$} \\
\hline & B & 0.00 & -0.72 & \\
\hline & $\mathrm{C}$ & 0.00 & -0.72 & \\
\hline & $\mathrm{D}$ & 7.00 & 0.86 & \\
\hline & $\mathrm{E}$ & 9.00 & 1.31 & \\
\hline \multirow{5}{*}{$\begin{array}{l}\text { 인허가 절차의 } \\
\text { 용이성 }\end{array}$} & $\mathrm{A}$ & 1.35 & 1.19 & \multirow{5}{*}{-용도지역 및 제한구역이 적은 지역 } \\
\hline & B & 1.19 & 0.62 & \\
\hline & $\mathrm{C}$ & 1.09 & 0.23 & \\
\hline & $\mathrm{D}$ & 0.80 & -0.84 & \\
\hline & $\mathrm{E}$ & 0.70 & -1.20 & \\
\hline
\end{tabular}


140 윤준상·최성현 · 김이기·김성록 / $\mathrm{AHP}$ 를 이용한 농촌관광단지 입지선정에 관한 연구

\begin{tabular}{|c|c|c|c|c|}
\hline \multirow{5}{*}{ 민원발생 가능성 } & A & 1.47 & 1.61 & \multirow{5}{*}{$\begin{array}{l}\text {-민원발생 가능성 } \\
\text { (인접주민, 상권 등 민원발생소지가 적 } \\
\text { 은 부지를 후보지별로 쌍대비교) }\end{array}$} \\
\hline & B & 1.11 & 0.32 & \\
\hline & $\mathrm{C}$ & 0.91 & -0.42 & \\
\hline & $\mathrm{D}$ & 0.81 & -0.75 & \\
\hline & $\mathrm{E}$ & 0.81 & -0.76 & \\
\hline \multirow{5}{*}{$\begin{array}{l}\text { 주변관광시설 } \\
\text { 연계성 }\end{array}$} & A & 4.76 & -0.64 & \multirow{5}{*}{$\begin{array}{l}\text {-백제문화단지, 나루터, 궁남지 등에서 } \\
\text { 의 지역접근이 용이한 지역 }\end{array}$} \\
\hline & B & 4.66 & -0.66 & \\
\hline & $\mathrm{C}$ & 4.16 & -0.78 & \\
\hline & $\mathrm{D}$ & 10.33 & 0.66 & \\
\hline & $\mathrm{E}$ & 13.66 & 1.44 & \\
\hline \multirow{5}{*}{ 주변 환경 } & $\mathrm{A}$ & 1.15 & 0.89 & \multirow{5}{*}{$\begin{array}{l}\text {-주변지역과의 친수성, 입목도 등이 좋 } \\
\text { 은 지역 }\end{array}$} \\
\hline & $\mathrm{B}$ & 1.14 & 0.81 & \\
\hline & $\mathrm{C}$ & 0.82 & -1.17 & \\
\hline & $\mathrm{D}$ & 1.08 & 0.44 & \\
\hline & $\mathrm{E}$ & 0.85 & -0.98 & \\
\hline
\end{tabular}

\subsection{2. 최종 입지 선정}

평가지표와 설문을 통해 도출된 값을 이용하여 각 지표와 후보지들 간 의 표준점수를 구하고, 최종 가중치와 표준점수를 곱하여, 각 후보지들 간의 점수를 합산하여 가장 높은 점수가 나온 후보지를 최종 적지로 선 정한다.

〈표 6〉과 같이 A지역의 후보지역이 0.717, B의 후보지역이 0.495, $\mathrm{C}$ 후보지역이 0.211 등 $\mathrm{A} \sim \mathrm{D}$ 까지 후보지의 평가점수가 높은 순서대로 나왔으며, 결과적으로 농촌관광단지가 들어서게 될 최적의 입지는 $\mathrm{A}$ 후 보지인 규암면 호암리로 나타났다. AHP 설문조사 시 A후보지인 규암면 호암리가 지형 조건이나 모든 면에서 좋았지만, $\mathrm{D}$ 후보지인 장암면 정암 리 일대, $\mathrm{E}$ 후보지인 장암면 장하리 일대의 지역을 선호하는 사람들의 의 견도 많았는데, 이유는 농촌관광단지 조성을 토대로 부여군 내의 관광지 
역 다변화를 통한 지역 활성화를 달성해야 한다는 것이다.

〈표 6〉최종입지점수

\begin{tabular}{c|c|c|c|c|c}
\hline 지표 & $\mathrm{A}$ & $\mathrm{B}$ & $\mathrm{C}$ & $\mathrm{D}$ & $\mathrm{E}$ \\
\hline 국도와의 접근 & 0.304 & 0.109 & 0.018 & -0.164 & -0.368 \\
\hline 터미널로의 접근 & 0.017 & 0.021 & 0.040 & -0.030 & -0.048 \\
\hline 개발 비용 & -0.104 & -0.036 & 0.007 & 0.047 & 0.087 \\
\hline 부지확보 용이성 & 0.068 & 0.068 & 0.068 & -0.080 & -0.123 \\
\hline 인허가 절차의 용이성 & 0.057 & 0.030 & 0.011 & -0.040 & -0.058 \\
\hline 민원발생 가능성 & -0.067 & -0.014 & 0.018 & 0.031 & 0.032 \\
\hline 주변관광시설 연계성 & 0.186 & 0.193 & 0.227 & -0.190 & -0.415 \\
\hline 주변 환경 & 0.256 & 0.124 & -0.178 & 0.067 & -0.149 \\
\hline 합 계 & 0.717 & 0.495 & 0.211 & -0.359 & -1.042 \\
\hline
\end{tabular}

\subsection{3. 최적 입지 후보지 현황}

부여군 농촌관광단지의 입지로 규암면 호암리에 해당하는 지역으로서 백제문화단지와 가깝고 공주에서 국도를 통해 부여로 진입하는 관광객들 과의 교통 접근성이 뛰어나며, 국도를 통해서 백제문화단지를 가는 이들 을 끌기에 충분한 지역이다. 고속도로를 이용하는 관광객들에게는 고속도 로 백제문화단지로 연결하는 4차선 도로가 개통되어 접근이 쉽고, 주변 관광지인 백제문화단지, 나루터, 궁남지 등이 가까우면서 그 밖에 다른 관광지와의 거리도 멀지 않아 많은 관광지를 보고 체험할 수 있으며, 공 주 서천 간 고속도로를 통해서 부여IC로 접근하는 관광객들을 기준으로 부여IC에서 대상지역과의 거리는 약 $9.7 \mathrm{~km}$, 천안 논산 고속도로를 통 해 서- 논산IC에서 접근하는 관광객들을 기준으로 서논산IC에서 대상지 역과의 거리는 약 $19.5 \mathrm{~km}$ 이다. 또한 국도로 접근하는 관광객들은 공주 시청을 기점으로 대상후보지까지 약 $29.3 \mathrm{~km}$, 서천방면에서 4 번 국도를 
통해서 대상지로 접근하는 관광객들은 서천에서 부여로 들어서는 기점으 로부터 대상지역까지 약 $30 \mathrm{~km}$ 이다. 또한 대상지역의 대부분이 4 대강 사 업의 일환으로 국 - 공유지로 부지 확보가 되어있는 상태라 이후 사업을 진행할 시에는 부지확보면에서는 문제의 소지가 없을 것으로 보인다.

\section{5. 결 론}

농촌은 농업이라는 1 차 산업과 특산물을 이용한 다양한 재화의 생산 (2차산업), 그리고 관광프로그램 등 각종 서비스를 창출(3차 산업)하여 이른바 6차 산업이라는 복합산업공간으로 변화되고 있다. 특히 농촌관광 산업은 고부가가치의 서비스 산업으로 인식되고 있어 각 지역이 경쟁적 으로 관광정책에 적극적으로 나서고 있다. 이 연구는 농촌관광단지 입지 선정에 있어서 $\mathrm{AHP}$ 기법을 적용하는 방법론을 제시하고, 그 실증분석으 로 부여군 농촌관광단지 입지선정의 요인들과 이들 요인을 $\mathrm{AHP}$ 기법에 실제 적용하여 최종입지를 선정하는 내용을 다루었다.

결정요인들은 3 개의 대항목과 8 개의 세부항목들로 분류하여 중요도 조사를 실시하였고, 엑셀2003을 활용하여 AHP분석을 실시하여 요인들 간의 상대적 중요도를 추출하였다. 계층분석에 따른 요인분석의 결과를 단계별로 계층분석하기 위해 35 개의 설문을 배포하였고, 이 중 30 개의 설문을 연구에 반영하였다. 연구결과, 대항목의 경우 관광환경이 0.441 로 가장 높게 나타났으며, 교통 접근성이 0.302 , 개발 용이성이 0.257 등의 순으로 나타났다. 평가인자별 종합가중치는 주변관광시설 연계성 (0.288)이 가장 중요하다고 판단하였으며, 그다음으로 국도와의 접근 (0.265), 주변환경(0.152), 부지확보 용이성(0.094), 개발 비용(0.074), 인허가 절차의 용이성(0.048), 민원발생 가능성(0.042), 터미널과의 접 
근(0.037) 순으로 그 중요성을 부과하고 있다.

$\mathrm{AHP}$ 분석 기법을 통하여 추출한 가중치를 토대로 평가점수를 도출하 고, 크게 3 분류로 나눈 지표의 가중치에 세부항목의 평가점수를 곱하여 나온 최종 평가 점수를 추출하였다. 이러한 과정을 거쳐 마지막 단계를 통해서 평가점수가 가장 높게 나온 지역은 $\mathrm{A}$ 후보지인 부여군 규암면 호 암리로 나타났다.

부여군 내 농촌 관광단지의 최적 입지로 선정된 곳을 토대로 추후 연 구를 통해 관광분야의 농촌 개발 사업을 보다 합리적으로 평가하고 더욱 더 넓은 영역에 대한 체계적인 연구를 통해 기존의 평가모형과의 차별성 을 부각시키는 노력이 필요하다고 판단된다. 우리나라의 관광단지 개발 은 대부분이 소수의 결정권자에 의해서 개발적지 결정이 이루어져 왔고 그 결과 합리적인 적지 선정이 이루어지지 않는 한계가 있었다. 본 연구 는 이러한 한계점을 최소화하기 위해 농촌 관광단지 입지 선정의 합리적 인 의사결정요인들의 중요도를 부여군 내에 단체장 및 회장, 관련 정부 기관 종사자를 대상으로 설문조사를 실시하여 측정항목들에 대한 우선순 위를 검토하였다. 또한 본 연구는 그동안 선행 연구를 토대로 평가인자 를 도출하였으나, 농촌 관광단지 개발 입지 선정에 있어서 관광단지의 평가인자가 부족하였다. 따라서 향후 연구는 보다 많은 농촌 관광단지 입지 선정의 평가인자를 도출해 내어 일반 관광지 입지 선정 연구와 명 확히 구분 짓고 보다 많은 해당 전문가 대상으로 $\mathrm{AHP}$ 쌍대비교의 충분 한 설명과 함께 설문조사를 실시할 필요성이 있다. 


\section{- 참 고 문 헌}

고병주. (2009). AHP를 활용한 해양 관광지 개발적지 선정을 위한 연구. 건국대학 교 석사학위논문.

김대관 - 박양우 - 이상민. (2007). AHP를 활용한 관광자원개발사업 평가. 관광연구 저널, 21(4), 5-18.

김성진. (2005). 관광자원개발을 위한 생태관광기회스펙트럼의 적용. 관광농업연구, 12(1), 209-242.

김영규, \& 노시천. (1997). AHP모형을 이용한 우리나라 중소기업의 부실화 원인진 단과 그 예방대책에 관한 실증연구. 재무관리연구, 14(2), 75-105.

남인석, \& 김충영. (1994). 연구개발 효율화를 위한 예산제도 개선 및 우선순위 설 정에 관한 연구. 과학기술정책원.

박재현. (2004). 분석적 계층과정(AHP)을 이용한 관광지 입지선정에 관한 탐색적 연구. 호텔관광연구, 6(1), 134-152.

오정한. (2010). 계층화분석기법(AHP)을 이용한 어촌관광활성화 요인에 관한 연구: 기장군 공수마을을 중심으로. 부경대학교 석사학위논문.

우찬복, \& 문경일. (1999). 관광지 입지선정을 위한 퍼지모형 구축에 관한 연구. 관 광연구저널, 23(1), 66-86.

Al-Harbi, K. A. (1979). Applications of the AHP in Project Management. International Journal of Project Management, 19, 19-27.

Bard, J. F. (1992). A Comparison of the Analytic Hierarchy Process with Multi-attribute Utility Theory: A Case Study. IIE Transaction, 24(5), 111-121.

Falkner, C. H., \& S. Benhajla. (1990). Multi-attribute Models in the Justification of CIM Ssystem. The Engineering Economist, 37(2), 126-133.

Ossadnik, W., \& O. Lange. (1999). AHP-based Evaluation of AHP-Software. European Journal of Operation Research, 118, 578-588.

Rangone, A. (1996). An Analytic Hierarchy Process Framework for Comparing the Overall Performance of Manufacturing Departments. International Jourmal of Operation \& Production Management, 16(8), 104-119.

Saaty, T. L. (1979). Applications of analytical hierarchies. Mathematics and Computers in Simulation. 


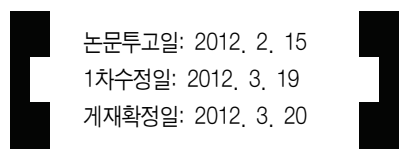

